\title{
The Effect of Inhaler Aromatherapy on Pain and Anxiety in Patients undergoing Shock Wave Lithotripsy
}

\author{
Şok Dalga Litotripsi Uygulanan Hastalarda İnhaler Aromaterapinin Ağrı ve Anksiyete Üzerine Etkisi
}

\author{
Barış SAYLAM \\ (1) 0000-0003-3256-8752 \\ Ozan EFESOY ${ }^{1}$ \\ (D) 0000-0002-5650-1686 \\ Erdem AKBAY ${ }^{2}$ \\ (D) 0000-0001-7669-414X \\ Erim ERDEM ${ }^{2}$ \\ (1) 0000-0003-1754-4365
}

\begin{abstract}
Aim: The aim of this study was to determine the effects of inhaler aromatherapy on pain and anxiety during the shock wave lithotripsy (SWL) protocol.

Material and Methods: This placebo-controlled prospective double-blind study included 120 patients who were scheduled to undergo SWL. Patients were randomly assigned a control placebo group $1(n=40)$, the lavender group $2(n=40)$, and the frankincense group $3(n=40)$. The nebulizer (a rate of $2 \%$ ) was prepared and operated on in the SWL room before the procedure. Data were collected using the visual analog scale (VAS) and the state-trait anxiety inventory (STAI-I).

Results: Of the 120 patients included in the study, 67 (55.8\%) were male and 53 (44.2\%) were female. The mean age of the patients was $37.38 \pm 11.35$ years. The mean stone size was $11.07 \pm 3.09 \mathrm{~mm}$. There were no statistically significant difference between the groups in terms of VAS scores of the patients after the procedure $(\mathrm{p}=0.557)$. While there was no statistically significant change in the STAI-I score in group 1 and group 2 after the procedure compared to the pre-procedure, a statistically significant decrease was detected in group $3(\mathrm{p}=0.030)$. The percentages of patients with changing STAI-I scores were compared, it was observed that the decrease in STAI-I score in group 2 and group 3 at a higher rate compared to group $1(\mathrm{p}=0.018)$. Conclusion: Frankincense reduced anxiety more significantly than lavender. Both had no significant effect on pain. Inhaler aromatherapy can be used in the SWL process to reduce anxiety and improve treatment compliance.

Keywords: Aromatherapy; SWL; lavender; frankincense; anxiety; pain.
\end{abstract}

ÖZ

Amaç: Bu çalışmanın amacı şok dalga litotripsi (shock wave lithotripsy, SWL) protokolü sırasında inhalasyon aromaterapisinin ağrı ve anksiyete üzerindeki etkilerinin belirlenmesidir. Gereç ve Yöntemler: Bu plasebo kontrollü prospektif çift kör çalışmaya SWL yapılması planlanan 120 hasta dahil edildi. Hastalar rastgele kontrol plasebo grubu $1(n=40)$, lavanta grubu $2(\mathrm{n}=40)$ ve günlük yağı grubu $3(\mathrm{n}=40)$ olarak ayrıldı. Nebülizör (\%2'lik bir oranda) işlemden önce SWL odasında hazırlandı ve çalıştırıldı. Veriler görsel analog skala (visual analog scale, VAS) ve durumluk-sürekli kaygı envanteri (state-trait anxiety inventory, STAI-I) kullanılarak toplandı.

Bulgular: Çalışmaya alınan 120 hastanın 67'si (\%55,8) erkek, 53'ü $(\% 44,2)$ kadındı. Hastaların yaş ortalaması $37,38 \pm 11,35$ yıl idi. Ortalama taş boyutu $11,07 \pm 3,09 \mathrm{~mm}$ idi. İşlem sonrası hastaların VAS skorları bakımından gruplar arasında istatistiksel olarak anlamlı bir farklılık yoktu ( $\mathrm{p}=0,557)$. Grup 1 ve grup 2'de işlem öncesine göre karşılaştırıldığında işlem sonrası STAI-I skorlarında istatistiksel olarak anlamlı bir değişiklik yokken, grup 3 'te istatistiksel olarak anlamlı bir düşüş saptandı $(\mathrm{p}=0,030)$. STAI-I skoru değişen hastaların yüzdeleri karşılaştırıldığında, STAI-I azalma oranının grup 2 ve grup 3 'te grup 1'e göre karşılaştırıldığında daha yüksek oranda olduğu gözlendi $(\mathrm{p}=0,018)$.

Sonuç: Günlük yağı kaygıyı lavantadan daha önemli ölçüde azalttı. Her ikisinin de ağrı üzerinde anlamlı bir etkisi olmadı. Anksiyeteyi azaltmak ve tedaviye uyumu artırmak için SWL sürecinde inhaler aromaterapi kullanılabilir.

Anahtar kelimeler: Aromaterapi; SWL; lavanta; günlük yağı; kaygı; ağrı.
Received / Gelis Tarihi : 29.10.2021 Accepted / Kabul Tarihi : 10.12.2021 Available Online /

Çevrimiçi Yayın Tarihi : 15.12.2021
(ClinicalTrials.gov Identifier: NCT04848350, 09.04.2021, retrospectively registered) 


\section{INTRODUCTION}

Shock wave lithotripsy (SWL) is widely and effectively used in the treatment of urinary tract stone disease (1). In the first applied lithotriptors, the energy density and maximum energy application at the skin level revealed the need for anesthesia in terms of pain. Later, with the development of new devices, the physics parameters were changed and shock was applied with lower energy levels, using large ellipsoids, the area where shock waves enter the skin is reduced and anesthesia is restricted (2). During the SWL procedure, patients can identify pain in the form of a subjective sensation that is difficult to identify. Pain occurs for two reasons. The first is the trauma caused by shock waves moving towards the kidney as they pass through the skin and muscles, and the second is the deep organ pain due to the trauma caused by shock waves in the kidney (2). Also, various patient-related and environmental factors affecting pain should be considered. The sedation of patients greatly facilitates SWL tolerance (3). However, it has been noted in various studies that patients with anxiety experience more pain during SWL (4). Aromatherapy is a tapas acupressure technique (TAT) method in which essential oils created from fragrant parts of plants are absorbed from the body and show their effects. The therapeutic, disease-relieving or preventive properties of essential oils are utilized (5). Essential oils can be applied to the body by topical, internal, oral, and inhalation methods (6). The fastest and easiest way of entry of essential oils into the body is inhalation. When applied through breathing, evaporating molecules reach the olfactory bulb through the nose and the limbic system in the brain. Aromatherapy provides control of pain and anxiety by affecting the amygdala and hippocampus, which regulate fear and aggressive behaviors in the limbic system (5). Aromatherapy by inhaler is used in hemodialysis, dental procedures, intrauterine contraceptive placement, pain and anxiety control in patients with arthritis (7-10). The literature shows that lavender (Lavandula officinalis) and frankincense (Boswellia) essential oils are used in pain and anxiety management in procedural pain and anxiety control $(11,12)$.

The aim of the study was to investigate the effects of inhaler aromatherapy on pain and anxiety during the SWL protocol.

\section{MATERIAL AND METHODS \\ Study design}

The study was carried out in the SWL unit of Mersin City Training and Research Hospital. The study was designed as a placebo-controlled prospective double-blind and approved by the Clinical Researches Ethics Committee of Mersin University (13.05.2020, 376). All patients who participated in the study were informed about the study and signed written consent forms 1 day before the SWL procedure. A total of 120 patients undergoing SWL unit were included in the study. Exclusion criteria were identified as; patients with pain before the procedure (VAS value is non-zero), and respiratory disease (lung cancer, asthma, bronchitis, chronic obstructive pulmonary disease, etc.), patients using painkillers in the last 3 hours, patients who were disturbed by the smell of used essential oils and patients with a known allergy to used essential oils with a history of contact dermatitis against cosmetic odor. Also, patients who used anxiolytic agents and narcotics were excluded. Patients with these characteristics were not included in the study. SWL was performed with an electro-hydraulic lithotripter (Multimed Classic, Elmed Lithotripsy Systems, Ankara, Turkey) with fluoroscopic guidance. The intensity of the shock wave started from $8 \mathrm{kV}$ and gradually increased to less than $18 \mathrm{kV}$. The number of shock waves was 2000 per session at a rate of 90 shocks per minute. The patients received the first session of their treatment.

\section{Randomization and Interventions}

The patients were grouped by using simple randomization method as placebo control group $1 \quad(n=40)$, lavender aromatherapy group $2 \quad(n=40)$ and frankincense aromatherapy group $3(n=40)$. They were filled out discomfort intolerance scale-Revised (DIS-R) forms before the procedure. Aromatherapy agents were added to the nebulizer at a rate of $2 \%(120 \mathrm{ml}$ of water). Only a saline solution was applied to the placebo group. The nebulizer was prepared and operated on in the SWL room before the procedure. The patients were taken to the room 5 minutes before the procedure and the nebulizer was operated on during the procedure. The level of anxiety was evaluated by the state-trait anxiety inventory (STAI) forms. The STAI index has 2 subheadings, STAI-1 (state index) and STAI-2 (trait index), with a total of 40 questions. The STAI form was used to state the transitory emotional state and anxiety level of the participants before and after the procedure. The interrogation procedures were carried out by an assistant doctor who did not know the study. After the patient was rested after the procedure, the patients have again filled out the STAI form and VAS pain scores (Figure 1). After that, the data of all the patients involved in the study were compared.

\section{Outcome Measurements}

The scale that evaluates the perceived physical discomfort intolerance, beliefs about physical discomfort, and responses to feelings of physical discomfort has been revised DIS-R (13). The DIS-R is a 5-item measure on which participants indicate, on a 7-point Likert-type scale

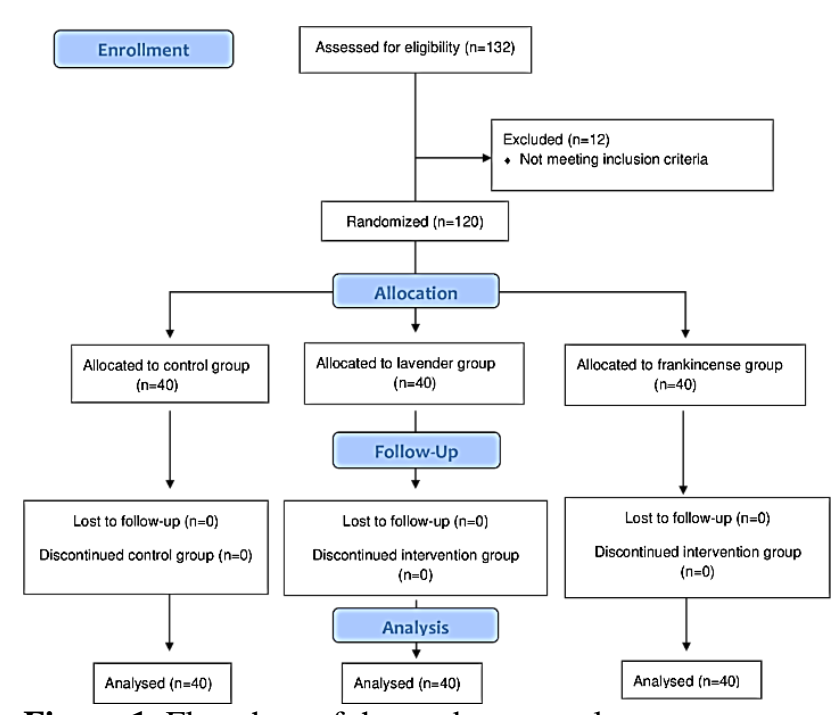

Figure 1. Flowchart of the study protocol 
(0: not at all like me to 6: extremely like me), the degree of agreement towards statements related to their tolerance of discomfort. The VAS pain scale was used to measure patients' pain levels. A patient is asked to indicate his/her perceived pain intensity (most commonly) along a $100 \mathrm{~mm}$ horizontal line, and this rating is then measured from the left edge, VAS score (14). The level of anxiety was assessed by the STAI-I. The STAI form is a psychological inventory based on a 4-point Likert scale and consists of 40 questions on a self-report basis. The STAI measures two types of anxiety; state anxiety, or anxiety about an event, and trait anxiety, or anxiety level as a personal characteristic. Higher scores are positively correlated with higher levels of anxiety (15).

\section{Statistical Analysis}

For statistical analyses SPSS (Statistical Package for the Social Sciences Inc, Chicago, IL, USA) version 21.0 package program was used, and $\mathrm{p}$ values less than 0.05 were qualified as statistically significant. Shapiro-Wilk as a normality test has performed for all parameters, and skewness and kurtosis were also evaluated. Descriptive statistics for continuous variables were expressed, and also tabulated as mean \pm standard deviation or median, interquartile range, minimum-maximum, as appropriate. Categorical variables were presented as frequencies, and percentages. One-Way ANOVA or Kruskal-Wallis test was used to compare groups. Pearson's chi-square test was used to analyze categorical variables and the percentage change of the scores in groups.

\section{RESULTS}

Of the 120 patients included in the study, 67 (55.8\%) were male and $53(44.2 \%)$ were female. The mean age of the patients was $37.38 \pm 11.35$ years. Sixty-five $(54.2 \%)$ of the stones was renal while $55(45.8 \%)$ were proximal ureteral. In total, $52(43.3 \%)$ of the stones were right sided, while $68(56.7 \%)$ were left, and the mean stone size was $11.07 \pm 3.09 \mathrm{~mm}$. No statistically significant difference was found between the groups in terms of socio-demographic data of the patients, DIS-R scores and the properties of the stones undergoing SWL (Table 1).

While there was no statistically significant change in the STAI-I score in group 1 and group 2 after the procedure compared to the pre-procedure, a statistically significant decrease was detected in group $3(\mathrm{p}=0.030)$. However, when the percentages of patients with changing STAI-I scores were compared, it was observed that the decrease in STAI-I in group 2 and group 3 at a higher rate compared to group $1(\mathrm{p}=0.018$, Table 2$)$. While there were 15 $(37.5 \%)$ patients in group 1 with decreased STAI scores after the procedure, there were $21(52.5 \%)$ patients in group 2 and $22(55.0 \%)$ patients in group 3. Accordingly, there were $15(37.5 \%)$ patients in group 1 whose STAI-I scores did not change from before to after the procedure, while there were only $3(7.5 \%)$ patients in group 2 and 8 $(20.0 \%)$ patients in group 3 . In some patients, the STAI-I score was elevated, similarly in the groups; 10 (25.0\%), 16 $(40.0 \%)$, and $10(25.0 \%)$, respectively.

When the VAS scores of the patients were compared after the procedure, no statistically significant difference was found between the groups $(\mathrm{p}=0.557$, Table 2$)$. Similarly, when the VAS values predicted before the procedure and the VAS values experienced after the procedure were compared, it was found that in all groups, the majority of patients experienced less and as much pain as they predicted, and there was no statistically significant difference between the groups $(p=0.708)$. None of the patients had allergic reactions due to aromatherapy.

Table 1. Comparison of sociodemographic characteristics and kidney stone locations and sizes of the patients

\begin{tabular}{|c|c|c|c|c|}
\hline & Group $1(n=40)$ & Group $2(n=40)$ & Group $3(n=40)$ & p value \\
\hline \multicolumn{5}{|l|}{ Gender, n (\%) } \\
\hline Male & $18(45.0)$ & $24(60.0)$ & $25(62.5)$ & \multirow{2}{*}{0.234} \\
\hline Female & $22(55.0)$ & $16(40.0)$ & $15(37.5)$ & \\
\hline Age (year), mean \pm SD & $36.93 \pm 10.56$ & $36.58 \pm 11.35$ & $38.65 \pm 12.57$ & 0.685 \\
\hline BMI $\left(\mathbf{k g} / \mathbf{m}^{2}\right)$, mean \pm SD & $26.09 \pm 2.93$ & $26.17 \pm 3.98$ & $28.23 \pm 4.35$ & 0.020 \\
\hline \multicolumn{5}{|l|}{ Educational level, n (\%) } \\
\hline Illiterate & $4(10.0)$ & $3(7.5)$ & $2(5.0)$ & \multirow{3}{*}{0.857} \\
\hline Primary school & $24(60.0)$ & $23(57.5)$ & $22(55.0)$ & \\
\hline High school & $12(30.0)$ & $14(35.0)$ & $16(40.0)$ & \\
\hline Stone size $(\mathbf{m m})$, mean \pm SD & $11.23 \pm 3.47$ & $11.43 \pm 2.55$ & $10.55 \pm 3.19$ & 0.419 \\
\hline \multicolumn{5}{|l|}{ Stone position, $\mathrm{n}(\%)$} \\
\hline Renal & $19(47.5)$ & $24(60.0)$ & $22(55.0)$ & \multirow{2}{*}{0.528} \\
\hline Proximal ureter & $21(52.5)$ & $16(40.0)$ & $18(45.0)$ & \\
\hline \multicolumn{5}{|l|}{ Stone side, $\mathrm{n}(\%)$} \\
\hline Right & $12(30.0)$ & $18(45.0)$ & $22(55.0)$ & \multirow{2}{*}{0.076} \\
\hline Left & $28(70.0)$ & $22(55.0)$ & $18(45.0)$ & \\
\hline DIS-R, mean \pm SD & $22.10 \pm 5.44$ & $19.63 \pm 5.81$ & $20.73 \pm 7.44$ & 0.216 \\
\hline
\end{tabular}

BMI: body mass index, DIS-R: discomfort intolerance scale-revised, SD: standard deviation

Table 2. VAS scores and STAI-I scores after intervention in the groups

\begin{tabular}{lcccc}
\hline & Group 1 $(\mathbf{n}=\mathbf{4 0})$ & Group 2 $(\mathbf{n = 4 0})$ & Group 3 $(\mathbf{n = 4 0})$ & p \\
\hline VAS, median $(I Q R)$ [min-max] & $3(4)[2-10]$ & $4(4)[1-9]$ & $3(2)[1-10]$ & 0.557 \\
Decrease in STAI-I, n (\%) & $15(37.5)$ & $21(52.5)$ & $22(55.0)$ & $\mathbf{0 . 0 1 8}$ \\
\hline
\end{tabular}

VAS: visual analog scale, STAI: state-trait anxiety inventory, IQR: interquartile range 


\section{DISCUSSION}

Pain is an unpleasant feeling felt in the face of potential harm (16). Therewithal anxiety is an uncomfortable state of mind or feeling of helplessness about a threatening situation or forecast (17). Aromatherapy is thought to have a therapeutic effect in conditions such as anxiety, depression, and chronic pain induced by stress by affecting the hippocampal formation and regions of the limbic system such as the hypothalamus and piriform cortex (18). Therefore, the present study aimed to compare the effect of aromatherapy using lavender and frankincense essential oils on the severity of anxiety and severity of pain during SWL. Less pain and anxiety can positively affect the success of SWL as it will increase the SWL duration and the amount of energy used (19). There are many studies in the literature examining the effect of lavender oil on anxiety and pain. However, fewer studies are available on the effect of frankincense oil on anxiety and pain. Frankincense has an anti-inflammatory effect by inhibiting 5 lipoxygenases and cyclooxygenase in the complement system and used has been used against many inflammatory diseases. It also has anxiety and pain relief effect (20). Studies reported that frankincense has antidepressant effects in addition to its protective effects in Alzheimer's patients (21).

In this study, we compared the effects of these two aromatic agents on anxiety and pain during the SWL procedure by an inhaler. We used the placebo group as the control group and randomized the patients according to their DIS-R scores. Abbasijahromi et al. (22) compared the effect of using lavender and Damask rose essential oils on the level of anxiety and severity of pain following C-section and they could not find a statistically significant difference between anxiety levels. Ayan et al. (18) investigated the effect of aromatherapy in patients with renal colic and found the effect of reducing pain. In our study, inhaler aromatherapy had no pain-reducing effect in both the lavender group and the frankincense group. In another study, inhaler lavender aromatherapy significantly decreased pain in female patients with renal colic. The pain did not significantly decrease in male patients, this condition may be due to differences in the gonadal hormones (23). But in our study, there is no difference between male and female patients. In the literature, the effect of lavender oil on pain and anxiety has always been emphasized. It has been shown that the use of lavender oil by inhalation significantly decreased pain after cesarean section and during needle insertion in hemodialysis patients $(24,25)$. Today, aromatherapy is used as therapeutic and ancillary therapy in many centers. Aromatherapy has become a legal part of holistic nursing (26).

\section{CONCLUSION}

In this study, it was found that frankincense reduced anxiety more significantly than lavender. Both had no significant effect on pain. Frankincense can be used via inhaler in certain procedures such as lavender to reduce the anxiety of patients and increase treatment compliance. More clinical studies are needed in different areas related to this. We used aromatherapy during SWL in urology practice. Urologists may perform aromatherapy for procedures that are usually done in the office setting such as biopsies, cystoscopies, and vasectomies.
Ethics Committee Approval: The study was approved by the Clinical Researches Ethics Committee of Mersin University (13.05.2020, 376).

Conflict of Interest: None declared by the authors.

Financial Disclosure: None declared by the authors.

Acknowledgements: None declared by the authors.

Author Contributions: Idea/Concept: BS, EE; Design: BS, EA, EE; Data Collection/Processing: BS, OE, EA; Analysis/Interpretation: BS, OE, EA; Literature Review: BS, OE; Drafting/Writing: BS, EE; Critical Review: BS, EA.

\section{REFERENCES}

1. Mishriki SF, Wills MI, Mukherjee A, Feneley RC, Gingell JC. Ureteric stone management using a second generation lithotriptor. Br J Urol. 1992;69(3):253-6.

2. Philp T, Kellett MJ, Whitfield HN, Wickham JE. Painless lithotripsy: experience with 100 patients. Lancet. 1988;1(8575-6):41-3.

3. Salinas AS, Lorenzo-Romero J, Segura M, Calero MR, Hernández-Millán I, Martínez-Martín M, et al. Factors determining analgesic and sedative drug requirements during extracorporeal shock wave lithotripsy. Urol Int. 1999;63(2):92-101.

4. Brown SM. Peri-operative anxiety in patients undergoing extracorporeal piezolithotripsy. J Adv Nurs. 1990;15(9):1078-82.

5. Lindquist R, Tracy MF, Snyder M. Complementary and alternative therapies in nursing. $8^{\text {th }}$ ed. New York, NY: Springer Publishing Company; 2018.

6. Başaran A. Natural aromatherapy: herbs \& essences. Turkiye Klinikleri J Med Sci. 2009;29(Suppl 1):86-94.

7. Shahnazi M, Nikjoo R, Yavarikia P, MohammadAlizadeh-Charandabi S. Inhaled lavender effect on anxiety and pain caused from intrauterine device insertion. J Caring Sci. 2012;1(4):255-61.

8. Itai T, Amayasu H, Kuribayashi M, Kawamura N, Okada M, Momose A, et al. Psychological effects of aromatherapy on chronic hemodialysis patients. Psychiatry Clin Neurosci. 2000;54(4):393-7.

9. Kim MJ, Nam ES, Paik SI. The effects of aromatherapy on pain, depression, and life satisfaction of arthritis patients. Taehan Kanho Hakhoe Chi. 2005;35(1):186-94.

10. Kritsidima M, Newton T, Asimakopoulou K. The effects of lavender scent on dental patient anxiety levels: a cluster randomized-controlled trial. Community Dent Oral Epidemiol. 2010;38(1):83-7.

11. Walsh E, Wilson C. Complementary therapies in longstay neurology in-patient settings. Nurs Stand. 1999;13(32):32-5.

12. Asad M, Alhomoud M. Proulcerogenic effect of water extract of Boswellia sacra oleo gum resin in rats. Pharm Biol. 2016;54(2):225-30.

13. McLeish AC, Kraemer KM, O'Bryan EM. Discomfort intolerance in relation to asthma outcomes. Cognit Ther Res. 2019;43(1):24-31.

14. Jones KR, Vojir CP, Hutt E, Fink R. Determining mild, moderate, and severe pain equivalency across pain- 
intensity tools in nursing home residents. J Rehabil Res Dev. 2007;44(2):305-14.

15. Spielberger CD. State-trait anxiety inventory. In: Weiner IB, Craighead WE, editors. The Corsini encyclopedia of psychology. $4^{\text {th }}$ ed. Hoboken, NJ: John Wiley; 2010.

16. Ochroch EA, Gottschalk A. Impact of acute pain and its management for thoracic surgical patients. Thorac Surg Clin. 2005;15(1):105-21.

17. Gorkem U, Togrul C, Sahiner Y, Yazla E, Gungor T. Preoperative anxiety may increase postcesarean delivery pain and analgesic consumption. Minerva Anestesiol. 2016;82(9):974-80.

18. Ayan M, Tas U, Sogut E, Suren M, Gurbuzler L, Koyuncu F. Investigating the effect of aromatherapy in patients with renal colic. J Altern Complement Med. 2013;19(4):329-33.

19. Bovelander E, Weltings S, Rad M, van Kampen P, Pelger RCM, Roshani H. The influence of pain on the outcome of extracorporeal shockwave lithotripsy. Curr Urol. 2019;12(2):81-7.

20. Ernst E. Frankincense: systematic review. BMJ. 2008;337:a2813.

21. Ammon HP. Boswellic acids in chronic inflammatory diseases. Planta Med. 2006;72(12):1100-16.
22. Abbasijahromi A, Hojati H, Nikooei S, Jahromi HK, Dowlatkhah HR, Zarean V, et al. Compare the effect of aromatherapy using lavender and Damask rose essential oils on the level of anxiety and severity of pain following C-section: A double-blinded randomized clinical trial. J Complement Integr Med. 2020;17(3).

23. Irmak Sapmaz H, Uysal M, Taş U, Esen M, Barut M, Somuk BT, et al. The effect of lavender oil in patients with renal colic: a prospective controlled study using objective and subjective outcome measurements. J Altern Complement Med. 2015;21(10):617-22.

24. Olapour A, Behaeen K, Akhondzadeh R, Soltani F, Al Sadat Razavi F, Bekhradi R. The effect of inhalation of aromatherapy blend containing lavender essential oil on cesarean postoperative pain. Anesth Pain Med. 2013;3(1):203-7.

25. Bagheri-Nesami M, Espahbodi F, Nikkhah A, Shorofi SA, Charati JY. The effects of lavender aromatherapy on pain following needle insertion into a fistula in hemodialysis patients. Complement Ther Clin Pract. 2014;20(1):1-4.

26. Kim JT, Wajda M, Cuff G, Serota D, Schlame M, Axelrod DM, et al. Evaluation of aromatherapy in treating postoperative pain: pilot study. Pain Pract. 2006;6(4):273-7. 